\title{
A Case of Giant Cell Tumor of the Metacarpal Bone Treated with Ray Amputation
}

\author{
Fekhaoui Mohammed Reda ${ }^{*}$, Ghannam Abdelaziz ${ }^{2}$, Krimech Mehdi Omar ${ }^{2}$, Boufettal Moncef ${ }^{3}$, Bassir Rida-Allah ${ }^{3}$, \\ Kharmaz Mohammed ${ }^{4}$, Lamarni Moulay Omar ${ }^{4}$, Berrada Mohammed Saleh ${ }^{4}$
}

\author{
${ }^{1}$ M.D., Department of Trauma and Orthopedic Surgery, Ibn Sina University Hospital, Faculty of Medicine, Mohamed V University of Rabat, Rabat, \\ Morocco \\ ${ }^{2}$ M.D. Department of Trauma and Orthopedic Surgery, Ibn Sina University Hospital, Rabat, Morocco \\ ${ }^{3} \mathrm{Ph} . \mathrm{D}$. Department of Anatomy, Faculty of Medicine, Mohamed V University of Rabat, Rabat, Morocco \\ ${ }^{4} \mathrm{Ph} . \mathrm{D}$, Department of Trauma and Orthopaedic Surgery, Ibn Sina University Hospital, Rabat, Morocco
}

DOI: $10.36347 /$ sjams.2020.v08i08.017

| Received: 13.08.2020 | Accepted: 20.08.2020 | Published: 24.08.2020

*Corresponding author: Fekhaoui Mohammed Reda

Abstract

Case Report

Giant cell tumors of the metacarpals bones are rare and commonly seen in the distal femur, proximal tibia or distal radius. It's a benign tumor locally aggressive with a tendency of local recurrence and may metastasize to lungs, ribs, regional lymph nodes, and skull. Few cases of GCT of metacarpals bones have been reported. We present the case of a 37-years-old man with a giant cell tumor of the second metacarpal bone. An effective surgical treatment must be done to prevent local recurrence since multiple surgical procedures may increase the chances of converting a benign tumor into a more malignant one. We treated our patient with ray amputation to prevent local recurrence and preserve as much as possible the function of the hand. After six months, there were no signs of local recurrence and the aesthetic and the functional results were very satisfying.

Keywords: Giant, cell, tumor, metacarpal, ray, amputation.

Copyright @ 2020: This is an open-access article distributed under the terms of the Creative Commons Attribution license which permits unrestricted use, distribution, and reproduction in any medium for non-commercial use (NonCommercial, or CC-BY-NC) provided the original author and source are credited.

\section{INTRODUCTION}

Giant cell tumor (GCT) or osteoclastoma is a benign tumor locally aggressive with a tendency of local recurrence and may metastasize to lungs, ribs, regional lymph nodes, and skull $[1,2]$. It involves epiphysio-metaphyseal region of mature long bones [3]. It's commonly seen in the distal femur, proximal tibia, distal radius and very few cases of GCT of metacarpals bones have been reported [4]. We present a rare case of giant cell tumor of the second metacarpal bone treated successfully with ray amputation.

\section{Case Presentation}

A 37-years-old man presented to us with a oneyear history of painful swelling of the right hand that had gradually affected movements of the index finger. His medical history was unremarkable. Physical examination found a diffuse mass of the right second metacarpal bone measuring $6 \times 5 \mathrm{~cm}$ and involving only the dorsal surface of the hand (Figure-1). Movements of metacarpo-phalangeal joint were restricted and painful. Radiography of the hand revealed an expansile osteolytic lesion involving the entire length of the second metacarpal and suggestive of giant cell tumor (Figure-2). CT confirmed an extensive cortical expansion and destruction (Figure-2). Therefore, a biopsy was done and the diagnosis of low-grade GCT confirmed. Due to the extent of the tumor, index Ray amputation was the choice because it would allow us a wide resection to prevent local recurrence and allow the long finger to takes over the pinching actions (Figure3 ). A percutaneous fixation of first and third metacarpal using K-wire was done then removed after 6 weeks. After six months, there were no signs of local recurrence. The aesthetic and functional results were very satisfying. 


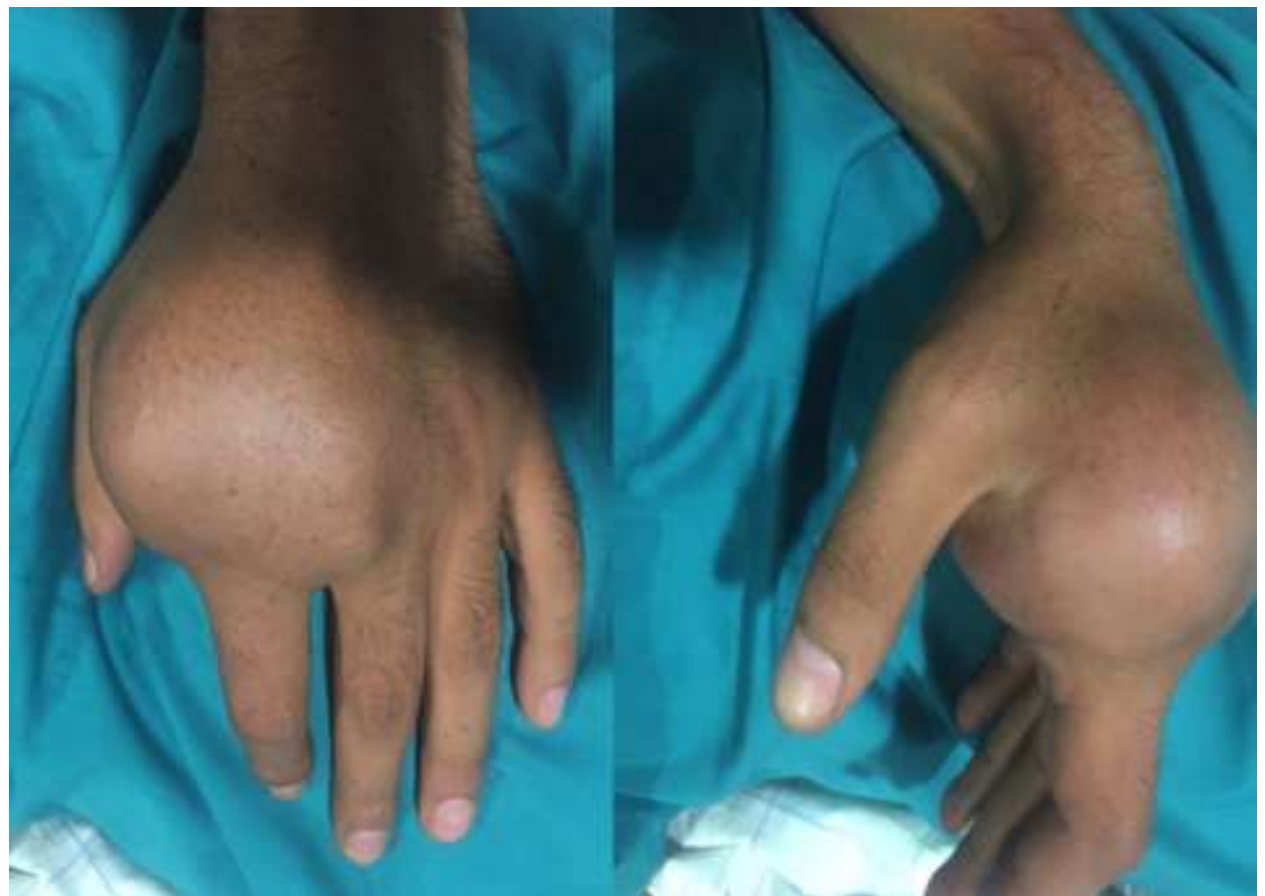

Fig-1: Clinical image showing a diffuse mass of the right hand involving the dorsal surface

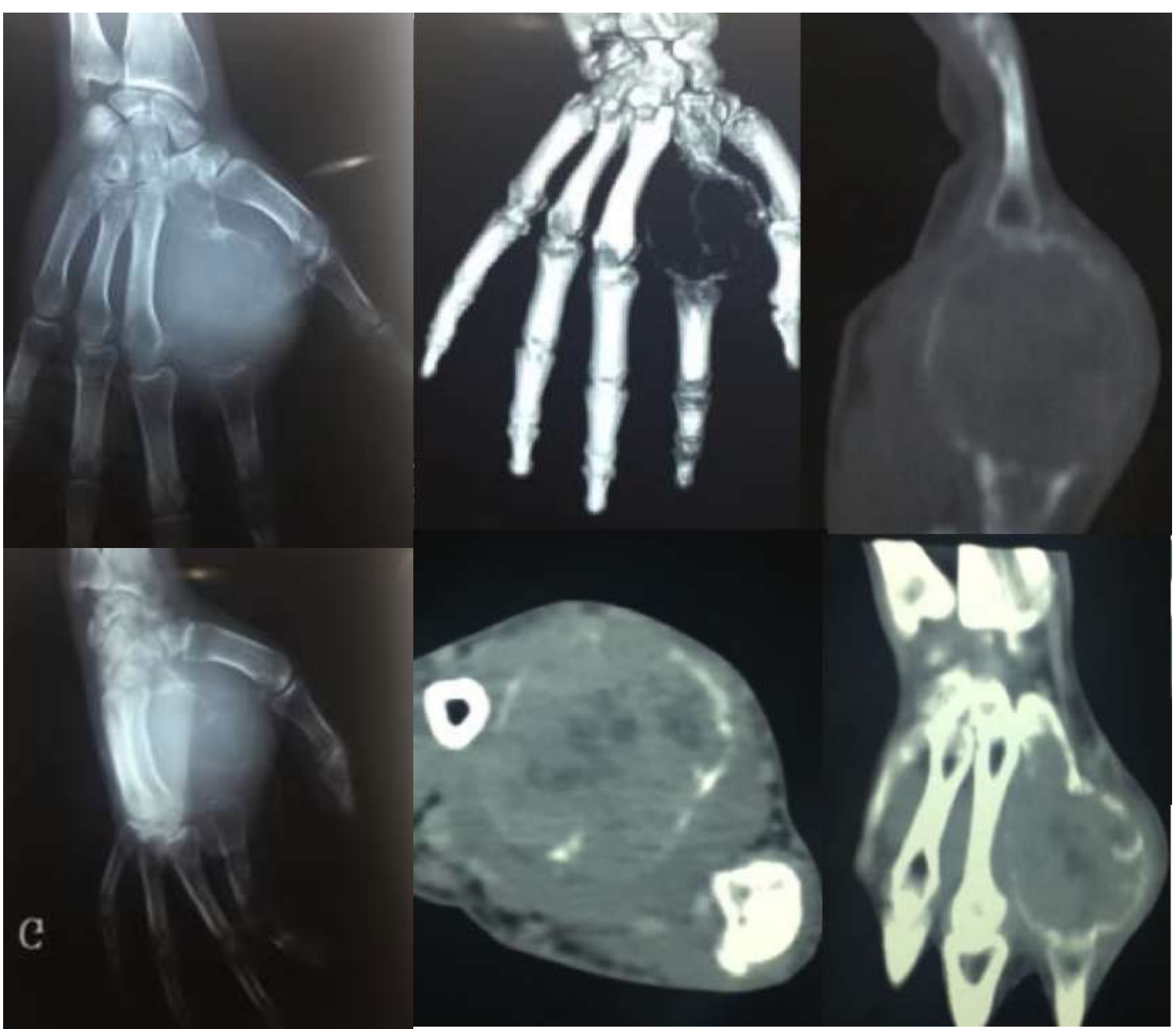

Fig-2: Radiography and CT of the hand showing a giant cell tumor of the second metacarpal with an extensive cortical expansion and destruction 


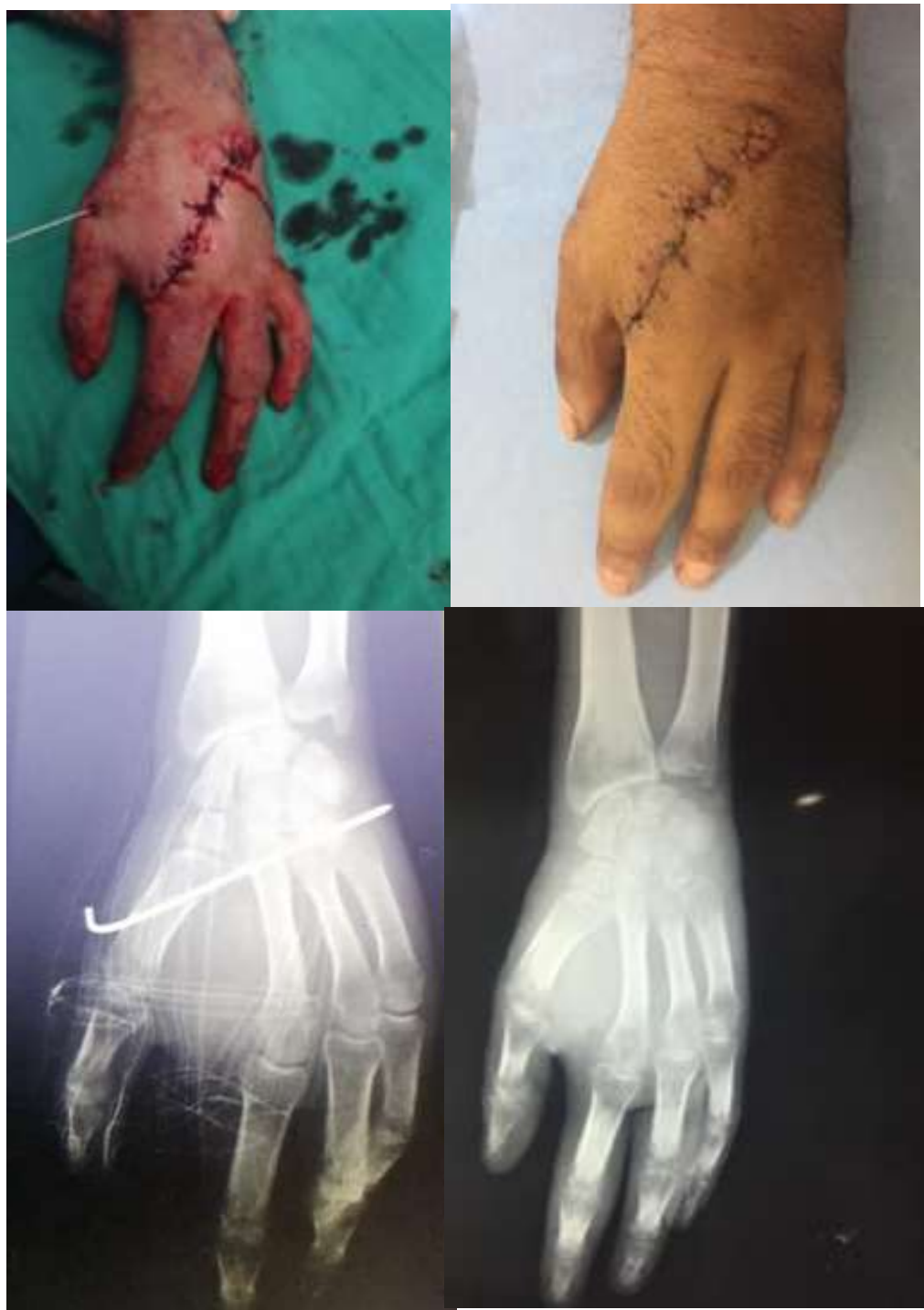

Fig-3: Clinical image and radiography after the index ray resection

\section{DISCUSSION}

Giant cell tumors of the metacarpals bones are rare (2\% of cases). It predominates in the long bones: $30 \%$ of cases in the femur, $25 \%$ of cases in the tibia, $10 \%$ of cases in radius and $6 \%$ of cases in the humerus. It's a benign but locally aggressive lesion with a high local recurrence rate $(30,7 \%$ to $88 \%)$ and distant metastasis [4-6]. They appear in a younger age group with female preponderance [7]. Lesions are in $1 \%$ of the cases multifocal [8]. The diagnosis requires clinical, radiological and histopathological evaluation as well as chest radiograph and bone scan to search for multicentric and metastasize lesions to the lungs [8]. Patients usually present with localized painful swelling, a limitation of joint movements, and pathological fracture. Radiography remains the mainstay of the diagnosis of GCT that manifests an eccentric lytic expansile mass that frequently extends from the subchondral bone plate into the metaphysic without any periosteal reaction. MRI needs to be done in cases of destruction of the cortex and soft tissue extension [9-
11]. Treatment modalities described in the literature are aggressive curettage or resection of the tumor followed by bone grafting, irradiation, wide resection or amputation $[4,8,6,12]$. Wide resection must be done in cases with extensive bone destruction to prevent local recurrence [4, 8]. Sanjay et al., and Ozalp et al., recommend wide resection or ray amputation to prevent further recurrences at the cost of losing a functional finger [13, 14]. Kabul CS et al., reported a case of GCT grade 3 of metacarpal bone treated by primary ray resection with good results [15]. Radiation is a treatment option for benign GCT of bone. Caudell et $a l$., recommend radiation as an alternative therapy to control the progression of unresectable tumor [16]. Singhal et al., reported successful use of radiation in the case of metacarpal GCT [17]. Radiation has been suggested if the lesions were incompletely removed and in patients with high mitotic activity [18]. Recurrence rates are from $7 \%$ to $15 \%$ after wide excision and about $90 \%$ after curettage with or without bone [19, 20]. Reconstruction of the hand after the excision is difficult [21] and joint reconstruction can be done by a combined 
iliac crest and metatarsal head graft or prosthetic replacement [22].

\section{Conclusion}

Giant cell tumors of the metacarpal bone are rare and should be kept in mind. They are locally aggressive with a high local recurrence rate. An effective surgical treatment must be done to prevent local recurrence and must preserve as much as possible the function of the hand. Adequate long-term follow-up must be undertaken and multiple surgical procedures may increase the chances of converting a benign tumor into a more malignant one.

Conflicts of Interest: The authors declare that they have no conflicts of interest.

Funding Statement: All authors disclose that this manuscript didn't receive no specific grant from any funding agency.

\section{ACKNOWLEDGMENTS}

Fekhaoui MR, Ghannam A and Krimech MO make substantial contributions to acquisition of data, conception, design, analysis and interpretation of data. Boufettal M, Bassir RA, Kharmaz M, Lamrani MO and Berrada MS participate in revising it critically for important intellectual content and give final approval of the version to be submitted

\section{REFERENCES}

1. Faizan M, Sabir AB, Khalid S, Jilani LZ, Siddiqui B, Abbas M. Giant cell tumor of acromion process with secondary aneurysmal bone cyst. Clin Cancer Investig J. 2016 Jul; 5(4): 342-344.

2. Saikia KC, Bhuyan SK, Ahmed F, Chandra D. Giant cell tumor of the metacarpal bones. Indian $\mathrm{J}$ Orthop. 2011 Sep-Oct; 45(5): 475-478.

3. Varshney M, Shahid M, Maheshwari V, Mubeen A, Gaur K. Duplication of appendix: an accidental finding. BMJ Case Rep. 2011 Mar 8; 2011.

4. Goldenberg RR, Campbell CJ, Bonfiglio M. Giant-cell tumor of bone: An analysis of two hundred and eighteen cases. J Bone Joint Surg Am. 1970 Jun; 52(4): 619-64.

5. Dhillon MS, Prasad P. Multicentric giant cell tumour of bone. Acta Orthop Belg. 2007 Jun; 73(3): 289-99.

6. Averill RM, Smith RJ, Campbell CJ. Giant-cell tumors of the bones of hand. J Hand Surg Am. 1980 Jan; 5(1): 39-50.

7. Babazadeh S, Broadhead ML, Slavin JL, Schlicht SM, Choong P. Giant Cell Tumor of metacarpal diaphysis. Eur J Radiol Extra. 2010 July; 75(1): 31-36.
8. Wittig JC, Simpson BM, Bickels J, Kellar-Graney KL, Malawe MM. Giant cell tumour of the hand: superior results with curetage, cryosurgey, and cementation. J Hand Surg Am. 2001 May; 26(3): 546-55.

9. James SL, Davies AM. Giant Cell Tumors of bone of the hand \& wrist: a review of imaging findings and differential diseases. Eur Radiol. 2005 Sep; 15(9): 1855-1866.

10. Murphey MD, Nomikos GC, Flemming DJ, Gannon FH, Temple HT, Kransdorf MJ. From the archives of AFIP. Imaging of giant cell tumor and giant cell reparative granuloma of bone: radiologic-pathologic correlation. Radiographics. 2001 Sep-Oct; 21(5): 1283-309.

11. Biscaglia R, Bacchini P, Bertoni F. Giant cell tumor of the bones of the hand and foot. Cancer 2000 May; 88(9): 2022-32.

12. Feigenberg SJ, Marcus Jr RB, Zlotecki RA, Scarborough MT, Berrey BH, Enneking WF. Radiation therapy for giant cell tumors of bone. Clin Orthop Relat Res. 2003 Jun;(411): 207-16.

13. Sanjay BK, Raj GA, Younge DA. Giant cell tumours of the hand. J Hand Surg Br. 1996 Oct; 21(5): 683-7.

14. Ozalp T, Yercan H, Okçu G, Ozdemir O, Coskunol E, Bégué T, Calli I. Giant-cell tumor of the hand: midterm results in five patients. Rev Chir Orthop Reparatrice Appar Mot. 2007 Dec; 93(8):842-7.

15. Kabul CS, Sanjeev KB, Firoz A, Debashish C. Giant cell tumor of the metacarpal bones. Indian $\mathrm{J}$ Orthop. 2011 Sep-Oct; 45(5): 475-478.

16. Caudell JJ, Ballo MT, Zargars GK, Lewis VO, Weber KL, Lin PP, Marco RA, El-Naggar AK, Benjamin RS, Yasko AW. Radiotherapy in the management of giant cell tumor of bone. Int $\mathrm{J}$ Radiat Oncol Biol Phys. 2003 Sep; 57(1): 158-65.

17. Singhal RM, Mukhopadhyay S, Tanwar RK, Pant GS, Julka PK. Case report: Giant cell tumour of metacarpals: report of three cases. Br J Radiol. 1994 Apr; 67(796): 408-10.

18. Cherla D, Hahn E Jr, Datiashvilli R. Meticulous surgical excision of a localized giant cell tumor of the tendon sheath. Eplasty. 2013 Mar; 13:ic36.

19. Liang P. Treatment progress on giant cell tumors of bone. Zhongguo Gu Shang. 2018 Mar; 31(3): 292-296.

20. Meals RA, Mirra MJ, Bernstein AJ. Giant cell tumor of metacarpal treated by cryosurgery. J Hand Surg Am. 1989 Jan; 14(1): 130-4.

21. McDonald DJ, Sim FH, McLeod RA, Dahlin DC Giant-cell tumor of bone. J Bone Joint Surg Am. 1986 Feb; 68(2): 235-42.

22. Kettelkamp DB, Ramsey P. Experimental and clinical autogenous distal metacarpal reconstruction. Clin Orthop Relat Res. 1971 Jan; 74: 129-37. 